\title{
The Move Toward a Cashless Society: Calculating the Costs and Benefits
}

\author{
DANIEL D. GARCIA-SWARTZ
}

LECG

ROBERT W. HAHN *

American Enterprise Institute-Brookings Joint Center for Regulatory Studies

ANNE LAYNE-FARRAR

LECG

\begin{abstract}
While the "cashless society" has not yet fully become a reality, payment choices by consumers and merchants have been moving the U.S. economy in that direction slowly and steadily over the past five decades. In this study, a companion paper to Garcia-Swartz (2006a) in this volume, we lay out the detailed cost and benefit calculations behind our analysis of the steady changes in transaction payment methods.
\end{abstract}

\section{Introduction}

This paper is a companion piece to our paper "The Move Toward a Cashless Society: A Closer Look at Payment Instrument Economics" (Garcia-Swartz et al., 2006a). Here, we explain the exact calculations we perform to obtain our cost and benefit estimates and describe the sources of our data, as presented in the companion paper. In addition, a third case study not included in the companion piece is presented here to illustrate differences in merchant cost sources. Each of the three case studies begins with merchant-reported marginal transaction processing costs. These costs are then updated to reflect changes to processing costs since the time of merchant data collection. Except where noted, all figures are in 2003 dollars. Following the merchant studies, initial retailer costs are based on the average transaction size for a given payment instrument.

The average transaction sizes vary considerably across payment instruments. In order to provide a uniform basis for payment instrument comparison, we recalculate merchant processing costs for two standard transaction sizes, the cash and check transaction sizes for the retailer. Our recalculation is not a linear scaling: we adjust each individual component

\footnotetext{
* Contact author. AEI-Brookings, 1150 17th St. NW, Washington, DC 20036. E-mail: rhahn@aeibrookings.org. We would like to thank Howard Chang, David Humphrey, Randy Kroszner, Richard Schmalensee, Joanna Stavins, and an anonymous referee for helpful comments and Murtaza Akhter, Irina Danilkina, Melissa Long, and Nese Nasif for excellent research assistance. The authors would like to thank the AEI-Brookings Joint Center and Visa U.S.A. for financial support. This paper reflects the views of the authors and not necessarily those of their affiliated institutions.
} 
of retailer cost, some of which vary with transaction size and some of which do not, to arrive at an estimated processing cost for the standard transaction size. We then add consumer, central bank, and commercial bank costs using a multitude of sources. Finally, we estimate merchant, consumer, central bank, and commercial bank benefits, again using a multitude of sources.

\section{Case study 1: Grocery store transactions}

The grocery store case study begins with the Food Marketing Institute's 1998 member survey of processing costs. ${ }^{1}$ Surveys were sent to all FMI member companies and 48 responded. According to FMI, the responses "account for 27 percent of the [food retailer] industry sales." We were unable to determine if the responses were representative of U.S. grocery stores.

The FMI study reports the "direct" costs to grocers of accepting cash, non-verified and verified checks, credit cards, and debit cards, among other grocery-specific instruments that we ignore here. Consistent with the focus on processing costs, allocations of corporate overhead and equipment costs are excluded from the FMI survey. Surprisingly, float costs are also excluded. Included are the costs of processing a payment at the checkout counter ("tender time"), the costs of preparing and transporting bank deposits ("deposit preparation time"), the explicit costs of financial institution services ("bank charges"), and costs specific to certain payment instruments ("other direct costs").

The variable "tender time" captures the cost of the time that register attendants must spend to process a transaction payment, not counting the time to ring up individual items. Specifically, tender time is counted "from the time the total amount is displayed on the cash register to the time payment is consummated." Time (in seconds) is then multiplied by the wage rate for cashiers (inclusive of fringe benefits). "Deposit preparation" measures the labor costs of preparing a typical paper bank deposit for a merchant's bank account, such as counting cash and reconciling the register drawer. Electronic payment methods are cleared online at the point of sale and therefore do not involve any deposit preparation. "Bank charges" are explicit fees, such as a deposit fee for cash and checks or bank processing fees for payment cards. "Other direct costs" capture miscellaneous costs associated with each type of payment, such as check losses and collection fees, credit card losses, ${ }^{2}$ and armored car costs for transporting cash to a bank. Finally, the cost per $\$ 100$ of sales translates the reported costs, which apply to the average transaction size for that payment type, to $\$ 100$ worth of sales. ${ }^{3}$

The FMI report apparently contains an accounting error in deposit preparation time costs. FMI states that this cost is calculated by dividing the time devoted to deposit preparation on a typical day by the typical number of transactions per day and then multiplying by the hourly labor rate for the appropriate clerical personnel (inclusive of fringe benefits). For checks, FMI reports each of these individual components, allowing us to verify the calculations. The numbers reported in the study do not match our results using FMI's stated method. In fact, the reported deposit preparation cost for checks is overstated

\footnotetext{
${ }^{1}$ Food Marketing Institute (1998).

${ }^{2}$ This category covers "charge backs" for merchants. Merchants are responsible for these refused charges under certain circumstances. When a card issuer or consumer questions a transaction because of a stolen card, dispute over receipt of goods or cashier error, retailers have to gather documentation from stores as proof of purchase. If they do not deliver this evidence within a set timeframe, the disputed amount is charged back to the retailer.

${ }^{3}$ For instance, the average cash transaction is $\$ 11.52$, so around 8.68 transactions comprise $\$ 100$ of sales. Thus, the per transaction cost scaled to $\$ 100$ of sales is $\$ 2.61 \approx 8.68 \mathrm{x} \$ 0.30$.
} 
by around 50 percent. In Table 2-1, we correct this error and update the costs as described below.

\begin{tabular}{|c|c|c|c|c|c|c|}
\hline & Cash & $\begin{array}{l}\text { Non- } \\
\text { Verified } \\
\text { Check }\end{array}$ & $\begin{array}{l}\text { Verified } \\
\text { Check }\end{array}$ & Credit & $\begin{array}{l}\text { Signature } \\
\text { Debit }\end{array}$ & PIN Debit \\
\hline Tender Time & 0.11 & 0.26 & 0.24 & 0.18 & 0.18 & 0.17 \\
\hline Deposit Preparation & 0.004 & 0.03 & 0.03 & 0 & 0 & 0 \\
\hline Bank Charges & 0.004 & 0.06 & 0.16 & 0.94 & 0.56 & 0.41 \\
\hline Other Direct Costs & $\underline{0.16}$ & 0.27 & 0.03 & 0.02 & 0 & 0 \\
\hline Per Transaction Total Cost & 0.27 & 0.63 & 0.46 & 1.14 & 0.75 & 0.57 \\
\hline $\begin{array}{l}\text { Average Purchase for } \\
\text { Payment Type }\end{array}$ & 11.52 & 54.24 & 54.24 & 44.50 & 33.00 & 41.05 \\
\hline Cost Scaled to $\$ 100$ of Sales & 2.35 & 1.16 & 0.85 & 2.56 & 2.26 & 1.39 \\
\hline
\end{tabular}

Table 2-1: Per transaction processing costs for various payment instruments, grocery store merchants, modified (\$)

Note: Numbers may not add due to rounding. Source:Food Marketing Institute, "A Retailer's Guide to Electronic Payment Systems Costs," 1998, updated by authors.

The figures in Table 2-1 are modified as compared to the original FMI report in several respects. First, the 1998 tender time cost FMI reported was based on time observations taken in 1994, over 10 years ago now. Because processing time for payment card transactions has fallen considerably since then, we use the tender times (in seconds) reported by a later FMI study. ${ }^{4}$ We then adjust the tender time and deposit preparation costs for all payment types to reflect wage changes since 1997, the year FMI calculated the cost figures. ${ }^{5}$ That is, we multiply the time figures reported by FMI (2000) by 2002 wages for cashier positions using the Bureau of Labor Statistics (BLS) wage data. The 1998 union-member food service cashier wage most closely matched the 1998 FMI figure (\$8.81 versus \$8.79) and was therefore the category used for 2002 wages. For deposit preparation costs, we use BLS wage data for accountants and bookkeepers, the closest category to the grocery store bookkeeper wages that the FMI study reports.

We also update the bank charges to reflect inflation for cash and check fees and to reflect increases in processing fees for payment cards. In particular, we use a weighted average of current merchant discount rates for grocers where the weights are equal to the

\footnotetext{
${ }^{4}$ FMI conducted another cost survey in 2000. This later study, however, combined several payment categories (verified with non-verified checks, credit with signature debit), was inconsistent with the two previous FMI study figures (the 1998 survey as well as the original 1994 survey), and did not include adequate documentation detailing calculations and explaining discrepancies with the earlier studies. As a result, we rely on the 1998 study for all but the tender time observations. The processing time for cash transactions actually rose between FMI's 1994 and 2000 observations, from 23 seconds to 28.5 seconds. All other processing times fell, some substantially. Although the sparse discussions available in the 2000 FMI report do not allow for certainty, it appears that time measurement methods were similar in 1994 (used in the 1998 FMI report) and 2000 - stop-watch timing by observation at a sub-sample of supermarkets.

${ }^{5}$ Based on our research, check truncation and electronic check conversion at the point of sale, which could lower check deposit preparation time, appears to be an extremely limited practice in grocery stores. Price Chopper appears to be the only supermarket chain that has begun implementing electronic check conversion; it had converted 6 of its 102 stores by December 2002. See Mulholland (2002).
} 
proportion of grocery sales accounted for by each payment card system. ${ }^{6}$ Cash and check bank charges are updated using the financial services CPI. Finally, we update other direct costs for cash (which includes armored car transport) to reflect inflation using the Bureau of Economic Analysis's chain-type price index for the "Services, Other" category. The other direct costs category for checks, credit and debit cards do not reflect items influenced by inflation. Check and payment card losses may change with the business cycle, increasing with declared bankruptcies for example, but changes of this nature are difficult to estimate. We are unaware of any evidence that either check or credit card losses as a percentage of transaction size have increased for merchants since 1997. In fact, FMI conducted a separate study in 2003 that confirms this fact. ${ }^{7}$ Note that we do not update average transaction sizes. Inflation measures indicate almost no increase in consumer food prices since 1997 and the average transaction sizes reported by FMI in 2000 are comparable to those reported in 1998.

Table 2-2 translates the cost elements reported in Table 2-1 to two standard grocery store transaction sizes, cash $(\$ 11.52)$ and checks $(\$ 54.24)$. We calculate bank charges for credit and signature debit transactions using the fees for 2002 supermarket merchant discount rates applied to the transaction size at hand. Grocers report paying only a flat per transaction fee for PIN debit, Visa signature debit purchases and check deposits, so these costs do not vary by transaction size. Signature debit fees for MasterCard (representing 21 percent of signature debit transactions ${ }^{8}$ ) do vary by transaction size for grocery stores. FMI reports check and credit card losses as a percentage of sales; we assume this percentage does not vary by transaction size.

The FMI study omits at least two significant components of merchants' marginal cost of processing payment instruments: 1) theft and counterfeit loss for cash and 2) float loss for all instruments. ${ }^{9}$ FMI conducted a separate survey in 2003 on grocery store loss expenses and prevention measures, which we employ for our estimate of grocer losses due to cash theft and counterfeiting. ${ }^{10}$ Merchants face float costs for most payment instruments - even cash can have a float cost if merchants are unable to deposit cash receipts in a timely fashion. ${ }^{11}$ Card systems typically reimburse merchants within one to two days for credit and charge card purchases. For signature debit cards and checks, the merchant typically waits two days before receiving funds from the customer's bank and with PIN debit the delay is typically one day. ${ }^{12}$ We assume it takes a day on average to make cash deposits.

\footnotetext{
${ }^{6}$ Current supermarket merchant discount fees were collected from company annual reports, various press articles, and Visa U.S.A. Visa U.S.A.'s PSPS survey provides grocery store credit, charge, and debit sales accounted for by the various card systems.

${ }^{7}$ See Food Marketing Institute (2003).

${ }^{8}$ The Nilson Report, No. 784 (March 2003).

${ }^{9}$ Recall that check loss and credit card charge-backs are already included in FMI's estimate for Other Direct Costs. Thus, adding cash theft and counterfeit loss provides a more even treatment of payment instruments and makes the costs more comparable.

${ }^{10}$ See Food Marketing Institute( 2003), supra note 7, at 8-10.

${ }^{11}$ We assume that merchants could invest funds at a rate of 2.61 percent (the November 2003 rate for U.S. savings bonds, as reported by the U.S. Department of the Treasury, Bureau of Public Debt).

${ }^{12}$ For checks, see Stavins (1997). For signature debit cards, see Ingenico (2002). For credit cards, see

"Survey of Credit Card Plans" (2003).
} 


\begin{tabular}{|c|c|c|c|c|c|c|}
\hline & Cash & $\begin{array}{l}\text { Non- } \\
\text { Verified } \\
\text { Check }\end{array}$ & $\begin{array}{l}\text { Verified } \\
\text { Check }\end{array}$ & Credit & $\begin{array}{l}\text { Signature } \\
\text { Debit }\end{array}$ & PIN Debit \\
\hline $\begin{array}{l}\text { Merchant Cost, Instrument-Specific Avg. } \\
\text { Transaction Size (Repeated from Table 2-1) }\end{array}$ & 0.27 & 0.63 & 0.46 & 1.14 & 0.75 & 0.57 \\
\hline $\begin{array}{l}\text { Merchant Cost, Cash Transaction } \\
\text { Size } \$ 11.52\end{array}$ & 0.27 & 0.41 & 0.44 & 0.60 & 0.68 & 0.57 \\
\hline $\begin{array}{l}\text { Merchant Cost, Check Transaction Size } \\
\$ 54.24\end{array}$ & 0.28 & 0.63 & 0.46 & 1.21 & 0.81 & 0.57 \\
\hline
\end{tabular}

Table 2-2: Per transaction processing costs for various payment instruments, grocery store merchants, fixed transaction size (\$)

Source: Authors' calculations.

Cash theft/counterfeit losses and float costs are added to merchant processing costs in Tables 2-3 and 2-4. In addition, these two tables expand the marginal cost analysis to include consumers, the central bank, and commercial banks. Table 2-3 uses the average cash transaction size of $\$ 11.52$, while Table 2-4 uses the average transaction size for checks of $\$ 54.24$.

The second implicit cost of using cash is seigniorage accruing to the government. Seigniorage can be defined in many ways, but the definition most closely matching our cost-benefit approach is fiscal seigniorage - the profit from printing currency, net of expenses, that the central bank actually has available for budgeting purposes. Unfortunately, the most recent estimate of fiscal seigniorage we were able to find was an annual average for 1981-1990. ${ }^{13}$ We divide that estimate of fiscal seigniorage, $\$ 11,202$ million, by 76,500 million cash transactions per 18 months (the average life span of frequently used paper currency) to yield 14.6 cents of seigniorage cost per cash transaction. We divide that amount by the average cash transaction size (\$24.41) to obtain the seigniorage cost per dollar spent, which is then multiplied by the transaction size at hand (here, \$11.52).

${ }^{13}$ See Neumann (1992). 


\begin{tabular}{|c|c|c|c|c|c|c|}
\hline & Cash & $\begin{array}{l}\text { Non- } \\
\text { Verified } \\
\text { Check }\end{array}$ & $\begin{array}{l}\text { Verified } \\
\text { Check }\end{array}$ & $\begin{array}{l}\text { Credit/ } \\
\text { Charge }\end{array}$ & $\begin{array}{l}\text { Signature } \\
\text { Debit }\end{array}$ & PIN Debit \\
\hline \multicolumn{7}{|l|}{ Merchant } \\
\hline Theft/Counterfeit & 0.03 & 0 & 0 & 0 & 0 & 0 \\
\hline Float & 0.001 & 0.002 & 0.002 & 0.002 & 0.002 & 0.001 \\
\hline Costs From Table 2-2 & $\underline{0.27}$ & 0.41 & 0.44 & 0.61 & 0.68 & 0.57 \\
\hline a) Merchant Marginal Cost & 0.30 & 0.42 & 0.44 & 0.61 & 0.68 & 0.57 \\
\hline \multicolumn{7}{|l|}{ Consumers } \\
\hline Processing Time & 0.14 & 0.33 & 0.31 & 0.23 & 0.23 & 0.21 \\
\hline Queue Time & 0.14 & 0.33 & 0.31 & 0.23 & 0.23 & 0.21 \\
\hline Explicit Price & 0.03 & 0.04 & 0.04 & 0 & 0 & 0.13 \\
\hline Implicit Price & 0.28 & 0 & 0 & 0 & 0 & 0 \\
\hline Seigniorage & $\underline{0.07}$ & 0 & 0 & 0 & 0 & 0 \\
\hline b) Consumer Marginal Cost & 0.65 & 0.70 & 0.65 & 0.46 & 0.46 & 0.55 \\
\hline \multicolumn{7}{|l|}{ Central Bank } \\
\hline Production & 0.001 & 0 & 0 & 0 & 0 & 0 \\
\hline Processing & $\underline{0.002}$ & 0.03 & 0.03 & 0 & 0 & 0 \\
\hline c) Central Bank Marginal Cost & 0.004 & 0.03 & 0.03 & 0 & 0 & 0 \\
\hline \multicolumn{7}{|l|}{ Commercial Banks } \\
\hline ATM Maintenance & 0.06 & 0 & 0 & 0 & 0 & 0 \\
\hline Production & 0 & 0 & 0 & 0.01 & 0.01 & 0.01 \\
\hline Processing & 0.004 & 0.12 & 0.12 & 0.27 & 0.26 & 0.26 \\
\hline Card Rewards & $\underline{\underline{0}}$ & 0 & 0 & 0.05 & 0 & 0 \\
\hline d) Commercial Bank Marginal Cost & 0.07 & 0.12 & 0.12 & 0.34 & 0.27 & 0.27 \\
\hline e) Sum of Marginal Costs (double count) & 1.02 & 1.27 & 1.24 & 1.41 & 1.42 & 1.40 \\
\hline f) Social Marginal Cost (no double count) & 0.99 & 1.18 & 1.05 & 0.99 & 0.92 & 0.86 \\
\hline
\end{tabular}

Table 2-3: Per transaction processing costs for various payment instruments grocery store cash transaction $\$ 11.52$ (\$)

Notes: Numbers may not add due to rounding. Sum of MC, e, is equal to $a+b+c+d$. Due to transfers across parties (such as merchant payments to banks), this figure double counts some cost elements. Social Marginal Cost, $\mathrm{f}$, eliminates any transfers that give rise to double counting.

Source: Authors' calculations.

The central bank is the second party added to the calculations. The Federal Reserve reports its check processing costs to Congress. ${ }^{14}$ While the bank does incur check processing costs as an intermediary, it is required by law to recover those costs in full from its customers. The Fed does not, however, recover the processing cost of handling currency and removing unfit bills. The Federal Reserve typically destroys the most frequently used

\footnotetext{
${ }^{14}$ The Federal Reserve's $89^{\text {th }}$ Annual Report to Congress, available online, http://www.federalreserve.gov/boarddocs/rptcongress/annual02/default.htm.
} 
5-dollar bills after just 15 months in circulation. ${ }^{15}$ We determine the per-transaction cost by allocating the 2002 annual production costs of $\$ 210$ million $^{16}$ across the number of cash transactions that the currency is capable of producing before being retired from circulation. ${ }^{17}$ Dividing this figure by the average cash transaction size $(\$ 24.41)$ gives the per-dollar figure, which is multiplied by the average grocery cash transaction size to arrive at the cost estimate reported. In 2002, 51 billion transactions were conducted in cash, implying 76.5 billion cash transactions over 18 months. ${ }^{18}$ Thus, each dollar in each transaction generates a production cost of just over .01 cent, or around .15 cents for an $\$ 11.52$ transaction. Employing the usable lifespan of other bills ( $\$ 1$ bills, $\$ 20$ bills) did not alter the cost estimate appreciably.

Commercial banks are the third and final party added to the calculations. Banks must maintain ATM machines and periodically refill them with cash. ${ }^{19}$ The per-transaction ATM maintenance cost is calculated by dividing the amount banks spend each month to maintain an off-premise ATM by the total number of supermarket cash transactions an off-premise ATM could generate monthly, which in turn is calculated as the monthly number of extractions times the potential number of supermarket transactions per extraction. ${ }^{20}$ The monthly maintenance costs are $\$ 1,090$. In 2002, 3,308 transactions occurred per ATM on a monthly basis, approximately 80 percent of which were withdrawals. ${ }^{21}$ Therefore, a total of 2,646.4 transactions were withdrawals. Allocating maintenance costs equally across all transactions implies that $\$ 871.99$ is due to withdrawals. Assuming that each withdrawal was for the average $\$ 60$, then 13,783 supermarket transactions at the $\$ 11.52$ size could have been generated per ATM each month. Dividing the $\$ 871.99$ cost by 13,783 yields a maintenance cost of around 6 cents per grocery transaction.

Just as with paper currency, the magnetic stripe on plastic cards wears out over time and must be replaced. About a tenth of the magnetic stripes on credit and debit cards fail within two years and most card issuing banks replace their plastic cards within this time period. ${ }^{22}$ The per-transaction card production cost is calculated by taking the cost per plastic card $(\$ 0.75)$ divided by the number of transactions per card over its two-year life span (around 66). ${ }^{23}$

As another card-related cost, banks must fund the reward programs they offer. For American Express, ${ }^{24}$ MasterCard, and Visa, we estimate this cost based on one of the most

\footnotetext{
${ }^{15}$ The average lifespan of both $\$ 1$ and $\$ 10$ bills is only 18 months. "Dollars and Cents, The Circulation of Money," The Federal Reserve Bank of Atlanta, http://www.frbatlanta.org/invoke brochure.cfm?objectid=83FD41E6-9AF0-11D5898400508BB89A83\&method=display body.

${ }^{16}$ Bureau of Engraving and Printing, 2002 CFO Report, United States Mint, 2001 Annual Report, http://www.moneyfactory.com/section.cfm/2/51. We count only the cost of paper currency. Metal currency has an extremely long lifespan, so the marginal cost element is not applicable to coins. Moreover, a large portion of the minting costs for coins each year is attributable to special editions and collectable items, which are not relevant in a discussion of transaction costs.

${ }^{17}$ We estimate the per-transaction cost instead of the per dollar cost because each bill is used multiple times before it is retired.

${ }^{18}$ The Nilson Report, supra note 8

${ }^{19}$ This is the regular upkeep cost of the machine, not the initial installation cost, which is considered overhead and not a per transaction cost. Maintenance includes cash replenishment, servicing, telephone costs, rent, and so on. See American Bankers Association ATM Fact Sheet, 2003, http://www.aba.com/NR/rdonlyres/00007096hamqwzkpfkrfzgvm/ATMFactSheet5.pdf.

${ }^{20}$ See id.

${ }^{21}$ See Costanzo (2002) and Breitkopf (2002).

${ }^{22}$ Cox (1989).

${ }^{23}$ The Nilson Report, No. 759 (March 2002); The Nilson Report, No. 760 (March 2002); The Nilson Report, supra note 8; The Nilson Report, No. 785 (April 2003); see also id.

${ }^{24}$ American Express is not technically a commercial bank. We include their costs here for convenience.
} 
popular rewards, airline miles. Issuers typically offer one mile for each dollar charged. ${ }^{25}$ In 2000 , issuers paid airlines one cent for each frequent flyer mile. ${ }^{26}$ Thus the average grocery store cash purchase made with a reward card cost the issuer around 12 cents. Approximately 40 percent of all reward cardholders have Amex, MasterCard, or Visa, ${ }^{27}$ so we weight the cost per transaction in commercial bank costs by 40 per cent for a cost contribution of 4.7 cents.

Another 6 percent of all reward cardholders have a Discover cash-back card. ${ }^{28}$ These cards carry no annual fee and rebate a portion of each purchase back to the cardholder. The rebates are set according to a schedule: 0.25 percent on the first $\$ 1,500$ of purchases, 0.50 percent on the next $\$ 1,500$, and 1.0 percent on purchases over $\$ 3,000$. The average charge on a Discover card was $\$ 1,711$ in $2005 .{ }^{29}$ Based on this schedule of rebates and the typical annual charges, adding one more charge of $\$ 11.52$ to a Discover card would earn the average Discover cardholder 5.8 cents. Assuming that the costs of running the reward program are largely fixed, we estimate the marginal cost of providing cash back at the amount given to consumers, 5.8 cents. Multiplying by the percent of cardholders with a Discover card yields a cost of 0.3 cents for the average cash transaction at a grocery. Thus, the full marginal cost to commercial banks of providing payment card rewards is 5 cents $(4.7+0.3)$.

Commercial banks also expend resources in processing payment instruments. Since we do not have direct information on commercial bank expenditures to process, sort, and handle paper currency, we assume competition results in costs equivalent to the price charged to merchants. ${ }^{30}$ Banks face two costs for check processing. ${ }^{31}$ First, they must pay intermediaries, including the Fed, for checks that cross bank network lines. Over 67 percent of all checks go through an intermediary. As a measure of the social cost of intermediary processing, we take 67 percent of the reported 4.5 cents per check cost for the Fed. That is, we assume that all intermediaries are as efficient as the Fed. The remaining 33 percent of checks are so-called "on-us" checks where the payer and payee are both within the same bank network. For on-us checks, commercial bank processing costs represent the full marginal cost of check processing. Table 2-3 reports these two costs summed. The final item under commercial bank processing is for payment card processing. This includes items like the cost of funds for consumers' billing grace period and any pertransaction coordination costs between the issuer, the acquirer, and the merchant. ${ }^{32} \mathrm{We}$ estimate these expenses using Visa U.S.A. cost studies.

\footnotetext{
${ }^{25}$ Citi AAdvantage Cards, (visited July 21, 2003)

http://www.citibank.com/us/cards/cardserv/worldcard/index.htm?ProspectID=4A2A0BFA94FA4B328C6A9 718C2B2B07D.

${ }^{26}$ Breitkopf (2000).

${ }^{27}$ Primedia Insight (2005).

${ }^{28}$ The Nilson Report, supra note 8. While Discover - currently run by Morgan Stanley - does not technically qualify as a "commercial bank," we include their costs here for convenience.

${ }^{29}$ Calculated as 2005 Total Sales Volume divided by the number of cards outstanding. See The Nilson Report, No. 851 (February 2006).

${ }^{30}$ Lacker discusses commercial banks' role in paper currency processing, but he does not provide estimates for the cost of that effort. Lacker (1993).

${ }^{31}$ See Stavins (1997) for a description of the tortuous path that the typical personal check travels before satisfying its payment function. Our estimate for commercial bank processing costs is calculated from itemized costs presented in Stavins (1997). An earlier study by Wells reports that commercial bank check processing costs were 15 cents per transaction in 1993.

${ }^{32}$ Cardholders with no outstanding credit benefit from float for around 25 days. Customers with current balances (those who have taken out credit) pay finance charges from the moment of purchase. We therefore only count the cost of funds for float for those customers with no balance, $55 \%$ of cardholders. Since we are interested in credit cards as payment mechanisms, and not as sources of credit per se, we ignore the finance fees associated with credit balances. This omission does not change the net social calculations, as the charges
} 
The last two lines in the table report marginal cost sums. The first simply adds merchant, consumer, central bank, and commercial bank costs while the second removes transfer payments. The first figure double counts some cost items so it does not represent social marginal cost. For instance, commercial banks report 3 cents in check processing charges paid to intermediaries, but the intermediary (such as the Federal Reserve) receives that 3 cents as income and in turn expends 3 cents in processing costs. For the simple sum, we count both the commercial bank cost and the Federal Reserve cost, thus reaching a marginal cost sum of 6 cents. In order to get the social marginal cost, we must subtract out transfer payments such as these because only 3 cents worth of resources were actually expended on check processing. ${ }^{33}$

Table 2-4 below reports the same calculations using the average grocery store check transaction size in place of the average cash transaction size. Several costs are affected by transaction size. ATM maintenance fees are higher here since the same costs are spread over fewer higher dollar transactions $(\$ 54.24$ versus $\$ 11.52) .{ }^{34}$ Bank processing costs are higher as well. For payment cards, the bank processing cost increase results primarily from the cost of funds used to pay merchants before consumers pay the card issuer. The implicit cost of cash increases for reasons discussed in the main paper.

Tables 2-5 and 2-6 add in benefits and calculate net social marginal cost (the sum of marginal costs minus social marginal benefits) for average grocery store cash and check transactions, respectively.

are transfer payments from consumers to card issuing banks. Including the charges would, however, affect the private net costs.

${ }^{33}$ For cash, the fees merchants pay to banks for cash deposits are subtracted, as are ATM fees that consumers pay to banks. For checks, the fees merchants pay to banks for check deposits and those that banks pay to the Federal Reserve for processing are subtracted. For payment cards, the fees that merchants pay to banks for processing and the fees that consumers pay to banks (PIN debit transaction fees in particular) are subtracted.

${ }^{34}$ Recall that this cost element is estimated by allocating maintenance costs among potential grocery transactions generated from the cash dispensed at the ATM. If each grocery transaction costs more but the total monthly cash extracted remains the same, maintenance costs will be allocated among fewer transactions. 


\begin{tabular}{|c|c|c|c|c|c|c|}
\hline & Cash & $\begin{array}{l}\text { Non- } \\
\text { Verified } \\
\text { Check }\end{array}$ & $\begin{array}{l}\text { Verified } \\
\text { Check }\end{array}$ & $\begin{array}{l}\text { Credit/ } \\
\text { Charge }\end{array}$ & $\begin{array}{l}\text { Signature } \\
\text { Debit }\end{array}$ & PIN Debit \\
\hline \multicolumn{7}{|l|}{ Merchants } \\
\hline Theft/Counterfeit & 0.14 & 0 & 0 & 0 & 0 & 0 \\
\hline Float & 0.004 & 0.01 & 0.01 & 0.01 & 0.01 & 0.004 \\
\hline From Table 2-2 & $\underline{0.28}$ & 0.63 & 0.46 & 1.21 & 0.81 & 0.57 \\
\hline a) Merchant Marginal Costs & 0.43 & 0.64 & 0.47 & 1.22 & 0.82 & 0.57 \\
\hline \multicolumn{7}{|l|}{ Consumers } \\
\hline Processing Time & 0.14 & 0.33 & 0.31 & 0.23 & 0.23 & 0.21 \\
\hline Queue Time & 0.14 & 0.33 & 0.31 & 0.23 & 0.23 & 0.21 \\
\hline Explicit Price & 0.03 & 0.04 & 0.04 & 0 & 0 & 0.13 \\
\hline Implicit Price & 0.65 & 0 & 0 & 0 & 0 & 0 \\
\hline Seigniorage & $\underline{0.33}$ & 0 & 0 & 0 & 0 & 0 \\
\hline b) Consumer Marginal Costs & 1.27 & 0.70 & 0.65 & 0.46 & 0.46 & 0.55 \\
\hline \multicolumn{7}{|l|}{ Central Banks } \\
\hline Production & 0.01 & 0 & 0 & 0 & 0 & 0 \\
\hline Processing & $\underline{0.002}$ & 0.03 & 0.03 & 0 & 0 & 0 \\
\hline c) Central Bank Marginal Cost & 0.01 & 0.03 & 0.03 & 0 & 0 & 0 \\
\hline \multicolumn{7}{|l|}{ Commercial Banks } \\
\hline ATM Maintenance & 0.30 & 0 & 0 & 0 & 0 & 0 \\
\hline Production & 0 & 0 & 0 & 0.01 & 0.01 & 0.01 \\
\hline Processing & 0.02 & 0.12 & 0.12 & 0.40 & 0.34 & 0.34 \\
\hline Rewards & $\underline{\underline{0}}$ & 0 & 0 & 0.24 & 0 & 0 \\
\hline d) Commercial Bank Marginal Cost & 0.31 & 0.12 & 0.12 & 0.65 & 0.35 & 0.35 \\
\hline e) Sum of MC (double counts) & 2.02 & 1.49 & 1.27 & 2.33 & 1.63 & 1.48 \\
\hline f) Social MC (no double counts) & 1.98 & 1.40 & 1.08 & 1.32 & 1.00 & 0.94 \\
\hline
\end{tabular}

Table 2-4: Per transaction processing costs for various payment instruments, grocery store parties, check transaction \$54.24 (\$)

Notes: Numbers may not sum due to rounding. Sum of MC, e, is equal to $a+b+c+d$. Due to transfers across parties (such as merchant payments to banks), this figure double counts some cost elements. Social Marginal Cost, $\mathrm{f}$, eliminates any transfers that give rise to double counting.

Source: Author's calculations. 


\begin{tabular}{|c|c|c|c|c|c|c|}
\hline & Cash & $\begin{array}{l}\text { Non- } \\
\text { Verified } \\
\text { Check }\end{array}$ & $\begin{array}{l}\text { Verified } \\
\text { Check }\end{array}$ & $\begin{array}{l}\text { Credit/ } \\
\text { Charge }\end{array}$ & $\begin{array}{l}\text { Signature } \\
\text { Debit }\end{array}$ & PIN Debit \\
\hline \multicolumn{7}{|l|}{ Consumers } \\
\hline Float & 0 & 0.002 & 0.002 & 0.01 & 0 & 0 \\
\hline Credit Option & 0 & 0 & 0 & 0.03 & 0 & 0 \\
\hline Record Keeping & 0 & 0.04 & 0.04 & 0.04 & 0.04 & 0.04 \\
\hline Cash Back Option & 0 & 0.15 & 0.15 & 0 & 0 & 0.13 \\
\hline Signature Debit & 0 & 0 & 0 & 0 & 0.13 & 0 \\
\hline Reward Cards & 0 & 0 & 0 & 0.10 & 0 & 0 \\
\hline Discover Cards & 0 & 0 & 0 & 0.003 & 0 & 0 \\
\hline Privacy & $\underline{0.12}$ & 0 & 0 & 0 & 0 & 0 \\
\hline Consumer Marginal Benefits & 0.12 & 0.19 & 0.19 & 0.18 & 0.16 & 0.16 \\
\hline \multicolumn{7}{|l|}{ Central Banks } \\
\hline Processing Revenue & 0.002 & 0.03 & 0.03 & 0 & 0 & 0 \\
\hline Seigniorage & $\underline{0.07}$ & 0 & 0 & 0 & 0 & 0 \\
\hline Central Bank Marginal Benefits & 0.07 & 0.03 & 0.03 & 0 & 0 & 0 \\
\hline \multicolumn{7}{|l|}{ Commercial Banks } \\
\hline Float & 0 & 0 & 0 & 0 & 0.002 & 0.001 \\
\hline Processing Revenue & $\underline{0.03}$ & 0.06 & 0.16 & 0.42 & 0.50 & 0.54 \\
\hline Commercial Bank Marginal Benefits & 0.03 & 0.06 & 0.16 & 0.42 & 0.50 & 0.54 \\
\hline Sum of Marginal Benefits & 0.22 & 0.28 & 0.38 & 0.60 & 0.66 & 0.70 \\
\hline Sum of Marginal Costs (Table 2-3) & $\underline{1.02}$ & 1.27 & 1.24 & 1.41 & 1.42 & 1.40 \\
\hline Net Social Marginal Cost & 0.80 & 0.99 & 0.87 & 0.80 & 0.76 & 0.70 \\
\hline
\end{tabular}

Table 2-5: Adding selected benefits, grocery store cash transaction \$11.52 (\$)

Notes: Numbers may not add due to rounding. Net Social Marginal Cost equals the Sum of Marginal Costs minus the Sum of Marginal Benefits.

Source: Author's calculations.

Checks, credit and charge cards provide consumers with some level of float. Analogous to float costs for merchants, we calculate the float benefit for consumers as earned interest for instrument-specific days-to-clearance. ${ }^{35}$ The option value to credit card credit is estimated using the renewal fee for a relatively similar form of credit: personal lines of unsecured bank credit. These credit lines typically have a minimum amount of several thousand dollars, ${ }^{36}$ but the interest rate terms are similar to credit cards. ${ }^{37}$ Once an

\footnotetext{
${ }^{35}$ As noted earlier, credit cards provide 25 days of float for customers current with their bills, checks provide 2 days for all users, signature debit transactions 2 days, and PIN debit transactions 1 day. We use a rate of 2.61 percent (the November 2003 rate for U.S. savings bonds, as reported by the U.S. Department of the Treasury, Bureau of Public Debt) to value consumer float (and merchant float costs as well).

${ }^{36}$ Brito and Hartley (1995).

${ }^{37}$ Wells Fargo Loans \& Lines of Credit-Product Comparison, (visited August 7, 2003) http://www.wellsfargo.com/per/loans credit/chart.jhtml; Wells Fargo Loans \& Lines of Credit-Products (visited August 8, 2003) http://www.wellsfargo.com/per/loans_credit/products.jhtml; Wells Fargo Loans \&
} 
unsecured line of credit is established, consumers must pay an annual fee to maintain it. This fee can be thought of as the option price of borrowing for the year. We therefore use the typical unsecured loan annual fee of $\$ 25$, spread over the minimum loan and multiplied by the transaction size, as a rough estimate of the per-dollar value of having the option to place a transaction on credit. The typical minimum loan is $\$ 5,000$. Thus, each dollar borrowed has an option value of one half a cent (25/5000). Multiplying by $\$ 11.52$ gives an option value of 5.8 cents for the average grocery store cash transaction. While many credit card users may value this option (otherwise we would expect to see greater use of charge cards as opposed to credit cards), unlike security options the credit option is provided free of charge. For this reason, we scale the estimated benefit by the number of consumers taking credit by paying only a portion of their monthly bill (approximately 54 percent). ${ }^{38}$

We estimate the benefit of record keeping using consumer surveys of analogous benefits. Stavins (1997) employs survey data that places the consumer value of receiving cancelled checks at 3.5 cents per check. We assume that consumers equally value the record keeping aspects of payment cards on a per-transaction basis.

Because consumers can reduce their need to make a separate trip to an ATM in order to obtain cash for other purchases by getting cash back at the point of sale, we assume the cash back benefit is equal to the implicit cost of obtaining cash from an ATM. We scale the estimate by the average cash-back amount and the percentage of debit transactions involving cash-back. Recall from the calculations above that the average ATM cash withdrawal is $\$ 60$ and that we assume consumers spend around 5 minutes in total getting to an ATM and withdrawing cash. At the average U.S. wage (in 2002), a typical ATM trip thus costs a consumer around $\$ 1.43$. The typical debit transaction cash-back at the POS is $\$ 24$ and approximately 22 percent of debit customers exercise this option. ${ }^{39}$ Similar statistics hold for cash-back with check transactions at groceries: 25 percent of checks include cash-back and the average amount is $\$ 25 .{ }^{40}$ Thus POS cash-back saves consumers 40 to 42 percent of a trip to an ATM (or delays the next trip to an ATM by 40 to 42 percent), implying savings of 57 to 60 cents per cash-back transaction. Scaling by the percent of consumers requesting cash-back, the benefit to society is 13 cents for debit and 15 cents for checks.

According to survey results, around 30 percent of debit cardholders prefer signature to PIN; another 30 to 40 percent prefer PIN to signature. ${ }^{41}$ We obtained survey data that asked consumers who prefer signature debit how much of a discount they would need to receive from a merchant to induce them to enter their PIN to verify a debit transaction. ${ }^{42}$ In particular, cardholders were asked if they would enter a PIN if a merchant asked them to. Thirty percent responded that they would not. ${ }^{43}$ This group was then asked whether the merchant could offer a discount on the purchase price to induce them to enter their PIN. Forty percent replied that they could be persuaded to use their PIN if a discount were offered. Survey results indicate that those consumers preferring signature to PIN debit place a significant dollar value on that preference (from 25 cents a transaction up to 50 percent of the transaction value). ${ }^{44}$ However, the survey methodology was distinctively

Lines of Credit-Rate Calculator, (visited August 8, 2003)

http://www.wellsfargo.com/per/loans credit/rates/index.jhtml? requestid=17336.

${ }^{38}$ Survey of Consumer Finances (2001).

${ }^{39} \mathrm{See}$ http://www.star-systems.com/r_startools.html, Debit Facts 2002, Debit Statistics 2002

${ }^{40}$ Murphy (1997).

${ }^{41}$ Stewart (1999).

${ }^{42}$ See id.

${ }^{43}$ Twenty-six percent said "No" and another 4 percent said "Not Sure."

${ }^{44}$ If estimates based on the survey instrument are used in the calculations above, signature debit emerges as significantly less costly than all other forms of payment. 
different from the accounting based estimates we employ for benefits to other payment instruments. ${ }^{45}$ We therefore chose to treat signature and PIN debit symmetrically and estimate signature-specific benefits at the PIN-specific cash-back benefit amount.

As noted earlier, around 43 percent of credit cardholders have cards that provide rewards of some kind, counting American Express, Visa and MasterCard reward cards and Discover "cash back" cards. We calculate the benefit to consumers from reward cards analogously to our calculation for the commercial bank cost in providing the rewards. For benefits, however, we use the price at which consumers can buy frequent flyer miles. In 2003, American Airlines offered its miles to consumers at 2.2 cents a mile, so each cash size transaction earned a reward equivalent to around 25 cents. ${ }^{46}$ Again scaling by the 40 percent of reward cardholders with Amex, MasterCard, or Visa, we obtain a social benefit estimate of 10 cents for the average cash-size transaction at a grocery.

Based on the same rebate schedule information used to calculate the cost of providing Discover cash back rewards, we estimate that the consumer benefit of such cards for an average grocery store cash purchase is 0.3 cents. In other words, the marginal cost of providing the reward is equal to the marginal benefit received by the consumer.

As the final consumer benefit, we estimate the value of privacy. We estimate this benefit based on loyalty card discounts. In supermarkets, shunning a loyalty card means forgoing product discounts. We can view these discounts, then, as the implicit benefit of providing personal information to a merchant. Consumers paying with cash (and not providing a loyalty card) must value their privacy at least as much as the discount forgone. We estimate the benefit at 1 percent of the transaction value, so the larger the transaction the greater the privacy benefit from using cash. ${ }^{47}$

Bank revenues are the final benefits category. As discussed earlier, the central bank earns a profit on the currency it produces: fiscal seigniorage. This element represents a transfer payment from consumers (cash users) to the Federal Reserve (cash producers). The fees that consumers and merchants pay to commercial banks for cash deposits/ATM withdrawals, check processing, and payment card processing are listed as revenues also. Debit cards also provide float for commercial banks as consumer funds are typically frozen at the time of purchase though merchant payments usually take a day or two.

Note that in order to calculate social net marginal costs, we must use the sum of marginal costs, which includes transfer payments. To see why, return to the check processing example from above. Banks pay 3 cents to the Federal Reserve, which then incurs 3 cents worth of processing costs for a total of 6 cents in summed marginal costs. If we use the social marginal cost figure (which excludes the transfer from the bank to the Fed), we would be left with 3 cents in costs and 3 cents in revenues for a net cost to society of zero, even though 3 cents were expended in processing. In other words, the revenue payments that are included in the benefits table take care of netting out the appropriate

\footnotetext{
${ }^{45}$ The survey calculates the value of a consumer's entire preference for signature over PIN debit, as opposed to estimating the value of the individual attributes a consumer may like about signature debit.

${ }^{46}$ Sager and Arndt (2003). Because we are concerned with marginal payment card use, the annual cost of a reward card (often around $\$ 50$ per year) is considered a fixed cost and is not included in the calculation.

${ }^{47}$ Many of the loyalty card programs we looked at advertised a greater percentage savings. However, the savings seemed only to apply to certain products or targeted special promotions, so we conservatively assume the overall benefit is approximately 1 percent. For example, the CVS Extra Care card, which is one of the largest loyalty programs, offers two percent back on most purchases. CVS website (visited June 28, 2004) http://www.cvs.com/CVSApp/cvs/gateway/promotion?pid=304\&layout=about. Similarly, the Upromise card awards rebates of 1 to 10 percent in the form of education savings plans, but the rebates only apply to specific purchases at limited establishments. For example, a Upromise loyalty card holder can receive a 1 percent rebate on Coca-Cola at a Safeway or Albertsons grocery store. Pender (2004).
} 
amount of the transfer payments, so the sum of marginal costs must be used as the cost figure in the net social marginal cost calculation.

Table 2-6 presents identical calculations to those in 2-5, but employs the grocery store average check transaction size of $\$ 54.24$ in place of $\$ 11.52$.

\begin{tabular}{|c|c|c|c|c|c|c|}
\hline & Cash & $\begin{array}{l}\text { Non- } \\
\text { Verified } \\
\text { Check }\end{array}$ & $\begin{array}{l}\text { Verified } \\
\text { Check }\end{array}$ & Credit & $\begin{array}{l}\text { Signature } \\
\text { Debit }\end{array}$ & PIN Debit \\
\hline \multicolumn{7}{|l|}{ Consumers } \\
\hline Float & 0 & 0.01 & 0.01 & 0.04 & 0 & 0 \\
\hline Credit Option & 0 & 0 & 0 & 0.02 & 0 & 0 \\
\hline Record Keeping & 0 & 0.04 & 0.04 & 0.04 & 0.04 & 0.04 \\
\hline Cash Back Option & 0 & 0.15 & 0.15 & 0 & 0 & 0.13 \\
\hline Signature Debit & 0 & 0 & 0 & 0 & 0.13 & 0 \\
\hline Reward Cards & 0 & 0 & 0 & 0.48 & 0 & 0 \\
\hline Discover Cards & 0 & 0 & 0 & 0.02 & 0 & 0 \\
\hline Privacy & $\underline{0.54}$ & 0 & 0 & 0 & 0 & 0 \\
\hline Consumer Marginal Benefits & 0.54 & 0.19 & 0.19 & 0.60 & 0.16 & 0.16 \\
\hline \multicolumn{7}{|l|}{ Central Bank } \\
\hline Processing Revenue & 0.002 & 0.03 & 0.03 & 0 & 0 & 0 \\
\hline Seigniorage & $\underline{0.33}$ & 0 & 0 & 0 & 0 & 0 \\
\hline Central Bank Marginal Benefits & 0.33 & 0.03 & 0.03 & 0 & 0 & 0 \\
\hline \multicolumn{7}{|l|}{ Commercial Banks } \\
\hline Float & 0 & 0 & 0 & 0 & 0.01 & 0.004 \\
\hline Processing Revenue & 0.05 & 0.06 & 0.16 & 1.01 & 0.63 & 0.54 \\
\hline Commercial Bank Marginal Benefits & 0.05 & 0.06 & 0.16 & 1.01 & 0.64 & 0.54 \\
\hline Sum of Marginal Benefits & 0.92 & 0.28 & 0.38 & 1.61 & 0.80 & 0.70 \\
\hline Sum of Marginal Costs (Table 2-4) & 2.02 & 1.49 & 1.27 & 2.33 & 1.63 & 1.48 \\
\hline Net Social Marginal Cost & 1.11 & 1.21 & 0.89 & 0.72 & 0.83 & 0.78 \\
\hline
\end{tabular}

Table 2-6: Adding selected benefits, grocery store check transaction \$54.24 (\$)

Notes: Numbers may not add due to rounding.

Source: Author's calculations.

\section{Case study 2: Discount store transactions}

In order to explore the effect of a different data source on a similar retail venue, we include an additional case study on discount store transactions. As with the grocery store case study, we begin the discount store case study with an industry-sponsored retailer survey, but this time use a study conducted by Coopers \& Lybrand. The original data, collected in 1994, are replicated below in Table 3-1. 


\begin{tabular}{llllll}
\hline \hline & Cash & Check & Visa/MC & Discover & $\begin{array}{l}\text { American } \\
\text { Express }\end{array}$ \\
\hline POS Time & 0.04 & 0.12 & 0.07 & 0.07 & 0.07 \\
Drawer Costs & 0.01 & 0.02 & 0.01 & 0.01 & 0.01 \\
Back Office Costs & 0 & 0.08 & 0.003 & 0.002 & 0.005 \\
Bank Charges & 0.005 & 0.06 & 0.67 & 0.48 & 1.34 \\
Float Costs & 0 & 0.02 & 0.03 & 0.02 & 0.04 \\
Losses & 0.003 & 0.16 & 0.01 & 0.01 & 0.01 \\
Other Costs & 0.01 & 0.001 & 0 & 0 & 0 \\
Per Transaction Total Cost & $\mathbf{0 . 0 7}$ & $\mathbf{0 . 4 7}$ & $\mathbf{0 . 7 9}$ & $\mathbf{0 . 6 0}$ & $\mathbf{1 . 4 8}$ \\
& & & & & 48.43 \\
Average Receipt for Payment Type & 15.49 & 43.93 & 41.21 & 37.60 & 4.05 \\
Cost Scaled to \$100 of Sales & 0.44 & 1.06 & 1.91 & 1.59 & 3.05 \\
\hline
\end{tabular}

Table 3-1: Per transaction costs for various payment instruments discount store merchants, Coopers (1994 \$)

Notes: Store cards (such as those issued by department stores) and "Other Cards" are excluded. Debit is reported as zero transactions.

Source: Coopers (1995).

Following the same method as employed for the grocery store case study, we updated the costs reported by Coopers. Table 3-2 presents the results. Merchant discount fees, float, and inflation adjustments are identical to those made in the first case study. One modification here does require separate attention, however. Because the Coopers study collected data from 1994, debit use was reported as zero by the discount store that was surveyed. Since debit is the fastest growing payment instrument in discount stores, we impute the costs for signature and PIN debit. We rely on reported costs for Visa and MasterCard credit cards in the Coopers survey, current debit merchant discount fees, and information about the relationship of debit to credit in the FMI study. ${ }^{48}$ For example, PIN debit transactions take approximately 92 percent as long to process as credit transactions at grocery stores, so we use 92 percent of the Coopers reported Visa/MasterCard POS time to estimate the PIN debit POS time.

\footnotetext{
${ }^{48}$ The vast majority of debit cards are Visa Check cards, a signature debit card. The Nilson Report, supra note 8; and The Nilson Report, No. 785 (April 2003).
} 


\begin{tabular}{|c|c|c|c|c|c|c|c|}
\hline & Cash & Check & $\begin{array}{l}\text { MC/Visa } \\
\text { Credit }\end{array}$ & Discover & $\begin{array}{l}\text { American } \\
\text { Express }\end{array}$ & $\begin{array}{l}\text { Signature } \\
\text { Debit }^{*}\end{array}$ & PIN Debit ${ }^{*}$ \\
\hline POS Time & 0.04 & 0.12 & 0.07 & 0.07 & 0.07 & 0.07 & 0.07 \\
\hline Drawer/Office & 0.01 & 0.11 & 0.01 & 0.01 & 0.01 & 0.01 & 0.01 \\
\hline Bank Charges & 0.01 & 0.09 & 0.80 & 0.54 & 1.25 & 0.75 & 0.44 \\
\hline Losses & 0.003 & 0.16 & 0.01 & 0.01 & 0.01 & 0.01 & 0 \\
\hline Float & 0.001 & 0.01 & 0.01 & 0.01 & 0.01 & 0.01 & 0.003 \\
\hline Other Costs & 0.02 & 0.001 & 0 & 0 & 0 & 0 & 0 \\
\hline $\begin{array}{l}\text { Per Transaction Total } \\
\text { Cost }\end{array}$ & 0.08 & 0.49 & 0.90 & 0.64 & 1.35 & 0.85 & 0.52 \\
\hline $\begin{array}{l}\text { Average Receipt for } \\
\text { Payment Type } \\
\text { Cost Scaled to } \$ 100 \text { of } \\
\text { Sales }\end{array}$ & 15.49 & 43.93 & 41.21 & 37.60 & 48.43 & 41.92 & 41.07 \\
\hline
\end{tabular}

Table 3-2: Per transaction processing costs for various payment instruments discount store merchants, modified (\$)

Notes: * PIN and signature debit are imputed as described in the text. Numbers may not add due to rounding. Source: Coopers (1995), updated by authors.

Since the calculation methods and sources used for consumer, central bank, and commercial bank costs and benefits are identical to those used for grocery store transactions, we present the cost and benefit tables below without any discussion of the estimates.

Cash Check MC/Visa Discover $\begin{array}{lll}\text { American } & \begin{array}{l}\text { Signature } \\ \text { Express }\end{array} & \text { Debit }\end{array}$ PIN Debit

Merchant Cost, Instrument-

Specific Avg. Transaction

Size (Repeated from Table

3-2)

0.08

0.49

0.90

0.64

1.35

0.85

0.52

Merchant Cost, Cash

Transaction Size \$15.49

0.08

0.38

0.39

0.31

0.49

0.53

0.52

Merchant Cost, Check

Transaction Size \$43.93

0.08

0.49

0.95

0.73

1.24

0.87

0.52

Table 3-3: Per transaction processing costs for various payment instruments discount store merchants, fixed transaction size (\$)

Source: Authors' calculations. 
Cash Check MC/Visa Discover $\begin{aligned} & \text { American Signature } \\ & \text { Express Debit }\end{aligned}$

\begin{tabular}{|c|c|c|c|c|c|c|c|}
\hline a) Merchant Marginal Costs & 0.08 & 0.38 & 0.39 & 0.31 & 0.49 & 0.52 & 0.52 \\
\hline \multicolumn{8}{|l|}{ Consumers } \\
\hline Processing Time & 0.08 & 0.27 & 0.17 & 0.17 & 0.17 & 0.17 & 0.15 \\
\hline Queue Time & 0.08 & 0.27 & 0.17 & 0.17 & 0.17 & 0.17 & 0.15 \\
\hline Explicit Price & 0.03 & 0.04 & 0 & 0 & 0 & 0 & 0.13 \\
\hline Implicit Price & 0.37 & 0 & 0 & 0 & 0 & 0 & 0 \\
\hline Seigniorage & 0.09 & 0 & 0 & 0 & 0 & 0 & 0 \\
\hline b) Consumer Marginal Costs & 0.65 & 0.58 & 0.33 & 0.33 & 0.33 & 0.33 & 0.43 \\
\hline \multicolumn{8}{|l|}{ Central Bank } \\
\hline Production & 0.002 & 0 & 0 & 0 & 0 & 0 & 0 \\
\hline Processing & 0.002 & 0.03 & 0 & 0 & 0 & 0 & 0 \\
\hline c) Central Bank Marginal Costs & 0.004 & 0.03 & 0 & 0 & 0 & 0 & 0 \\
\hline \multicolumn{8}{|l|}{ Commercial Banks } \\
\hline ATM Maintenance & 0.09 & 0 & 0 & 0 & 0 & 0 & 0 \\
\hline Production & 0 & 0 & 0.01 & 0.01 & 0.01 & 0.01 & 0.01 \\
\hline Processing & 0.01 & 0.12 & 0.29 & 0.29 & 0.29 & 0.27 & 0.27 \\
\hline Rewards & $\underline{\underline{0}}$ & 0 & 0.07 & 0.08 & 0.07 & 0 & 0 \\
\hline d) Commercial Bank Marginal Costs & 0.09 & 0.12 & 0.37 & 0.38 & 0.37 & 0.28 & 0.28 \\
\hline e) Sum of MC (double counts) & 0.83 & 1.12 & 1.09 & 1.02 & 1.19 & 1.14 & 1.23 \\
\hline f) Social MC (no double counts) & 0.79 & 0.99 & 0.79 & 0.80 & 0.79 & 0.71 & 0.67 \\
\hline
\end{tabular}

Table 3-4: Per transaction processing costs for various payment instruments discount store parties, cash transaction $\$ 15.49$ (\$)

Notes: Numbers may not sum due to rounding. Sum of $M C, e$, is equal to the sum of $a+b+c+d$. Due to transfers across parties (such as merchant payments to banks), this figure double counts some cost elements. Social Marginal Cost, f, eliminates any transfers that give rise to double counting.

Source: Author's calculations. 


\begin{tabular}{|c|c|c|c|c|c|c|c|}
\hline & Cash & Check & MC/Visa & Discover & $\begin{array}{l}\text { American } \\
\text { Express }\end{array}$ & $\begin{array}{l}\text { Signature } \\
\text { Debit }\end{array}$ & PIN Debit \\
\hline a) Merchant Marginal Costs & 0.08 & 0.49 & 0.95 & 0.73 & 1.24 & 0.88 & 0.52 \\
\hline \multicolumn{8}{|l|}{ Consumers } \\
\hline Processing Time & 0.08 & 0.27 & 0.17 & 0.17 & 0.17 & 0.17 & 0.15 \\
\hline Queue Time & 0.08 & 0.27 & 0.17 & 0.17 & 0.17 & 0.17 & 0.15 \\
\hline Explicit Price & 0.03 & 0.04 & 0 & 0 & 0 & 0 & 0.13 \\
\hline Implicit Price & 0.73 & 0 & 0 & 0 & 0 & 0 & 0 \\
\hline Seigniorage & 0.26 & 0 & 0 & 0 & 0 & 0 & 0 \\
\hline b) Consumer Marginal Costs & 1.19 & 0.58 & 0.33 & 0.33 & 0.33 & 0.33 & 0.43 \\
\hline \multicolumn{8}{|l|}{ Central Bank } \\
\hline Production & 0.01 & 0 & 0 & 0 & 0 & 0 & 0 \\
\hline Processing & $\underline{0.002}$ & 0.03 & 0 & 0 & 0 & 0 & 0 \\
\hline c) Central Bank Marginal Costs & 0.01 & 0.03 & 0 & 0 & 0 & 0 & 0 \\
\hline \multicolumn{8}{|l|}{ Commercial Banks } \\
\hline ATM Maintenance & 0.24 & 0 & 0 & 0 & 0 & 0 & 0 \\
\hline Production & 0 & 0 & 0.01 & 0.01 & 0.01 & 0.01 & 0.01 \\
\hline Processing & 0.01 & 0.12 & 0.37 & 0.37 & 0.37 & 0.33 & 0.32 \\
\hline Rewards & $\underline{\underline{0}}$ & 0 & 0.19 & 0.22 & 0.19 & 0 & 0 \\
\hline $\begin{array}{l}\text { d) Commercial Bank Marginal } \\
\text { Costs }\end{array}$ & 0.25 & 0.12 & 0.58 & 0.61 & 0.58 & 0.34 & 0.34 \\
\hline e) Sum of MC (double counts) & 1.53 & 1.22 & 1.86 & 1.67 & 2.14 & 1.55 & 1.29 \\
\hline f) Social MC (no double counts) & 1.49 & 1.10 & 1.01 & 1.04 & 1.01 & 0.77 & 0.72 \\
\hline
\end{tabular}

Table 3-5: Per transaction processing costs for various payment instruments discount store parties, check transaction $\$ 43.93(\$)$

Notes: Numbers may not sum due to rounding. Sum of MC, e, is equal to the sum of $a+b+c+d$. Due to transfers across parties (such as merchant payments to banks), this figure double counts some cost elements. Social Marginal Cost, $\mathrm{f}$, eliminates any transfers that give rise to double counting.

Source: Author's calculations. 
Cash Check MC/Visa Discover $\begin{aligned} & \text { American Signature } \\ & \text { Express Debit }\end{aligned}$ PIN Debit

\begin{tabular}{|c|c|c|c|c|c|c|c|}
\hline \multicolumn{8}{|l|}{ Consumers } \\
\hline Float & 0 & 0.002 & 0.01 & 0.01 & 0.01 & 0 & 0 \\
\hline Credit Option & 0 & 0 & 0.04 & 0.04 & 0.04 & 0 & 0 \\
\hline Record Keeping & 0 & 0.04 & 0.04 & 0.04 & 0.04 & 0.04 & 0.04 \\
\hline Cash Back Option & 0 & 0 & 0 & 0 & 0 & 0 & 0.13 \\
\hline Signature Debit & 0 & 0 & 0 & 0 & 0 & 0.13 & 0 \\
\hline Reward Cards & 0 & 0 & 0.15 & 0.08 & 0.15 & 0 & 0 \\
\hline Privacy & $\underline{0.16}$ & 0 & 0 & 0 & 0 & 0 & 0 \\
\hline Consumer Marginal Benefits & 0.16 & 0.04 & 0.24 & 0.17 & 0.24 & 0.16 & 0.16 \\
\hline \multicolumn{8}{|l|}{ Central Bank } \\
\hline Processing Revenue & 0.002 & 0.03 & 0 & 0 & 0 & 0 & 0 \\
\hline Seigniorage & 0.09 & 0 & 0 & 0 & 0 & 0 & 0 \\
\hline Central Bank Marginal Benefits & 0.10 & 0.03 & 0 & 0 & 0 & 0 & 0 \\
\hline \multicolumn{8}{|l|}{ Commercial Banks } \\
\hline Float & 0 & 0 & 0 & 0 & 0 & 0.002 & 0.001 \\
\hline Processing Revenue & $\underline{0.04}$ & 0.09 & 0.30 & 0.22 & 0.40 & 0.43 & 0.57 \\
\hline Commercial Bank Marginal Benefits & 0.04 & 0.09 & 0.30 & 0.22 & 0.40 & 0.43 & 0.57 \\
\hline Sum of Marginal Benefits & 0.29 & 0.16 & 0.54 & 0.39 & 0.64 & 0.59 & 0.73 \\
\hline Sum of Marginal Costs (Table 3-4) & 0.83 & 1.12 & 1.09 & 1.02 & 1.19 & 1.14 & 1.23 \\
\hline Net Social Marginal Cost & 0.54 & 0.96 & 0.55 & 0.63 & 0.55 & 0.54 & 0.51 \\
\hline
\end{tabular}

Table 3-6: Adding selected benefits, discount store cash transaction $\$ 15.49$ (\$)

Notes: Numbers may not add due to rounding.

Source: Author's calculations.

Note that since the different brands of credit card are reported separately in this case, the benefits are calculated separately as well. Thus, for reward cards, American Express, MasterCard, and Visa each receive the full benefit of mileage as calculated above, without weighting by the proportion of reward card holders to obtain the average necessary for the grocery store calculations. Likewise, Discover card rewards reports the full cash back amount. 


\begin{tabular}{|c|c|c|c|c|c|c|c|}
\hline & Cash & Check & MC/Visa & Discover & $\begin{array}{l}\text { American } \\
\text { Express }\end{array}$ & $\begin{array}{l}\text { Signature } \\
\text { Debit }\end{array}$ & PIN Debit \\
\hline \multicolumn{8}{|l|}{ Consumers } \\
\hline Float & 0 & 0.01 & 0.04 & 0.04 & 0.04 & 0 & 0 \\
\hline Credit Option & 0 & 0 & 0.12 & 0.12 & 0.12 & 0 & 0 \\
\hline Record Keeping & 0 & 0.04 & 0.04 & 0.04 & 0.04 & 0.04 & 0.04 \\
\hline Cash Back Option & 0 & 0 & 0 & 0 & 0 & 0 & 0.13 \\
\hline Signature Debit & 0 & 0 & 0 & 0 & 0 & 0.13 & 0 \\
\hline Reward Cards & 0 & 0 & 0.42 & 0.22 & 0.42 & 0 & 0 \\
\hline Privacy & $\underline{0.44}$ & 0 & 0 & 0 & 0 & 0 & 0 \\
\hline Consumer Marginal Benefits & 0.44 & 0.04 & 0.61 & 0.41 & 0.61 & 0.16 & 0.16 \\
\hline \multicolumn{8}{|l|}{ Central Bank } \\
\hline Processing Revenue & 0.002 & 0.03 & 0 & 0 & 0 & 0 & 0 \\
\hline Seigniorage & 0.26 & 0 & 0 & 0 & 0 & 0 & 0 \\
\hline Central Bank Marginal Benefits & 0.27 & 0.03 & 0 & 0 & 0 & 0 & 0 \\
\hline \multicolumn{8}{|l|}{ Commercial Banks } \\
\hline Float & 0 & 0 & 0 & 0 & 0 & 0.01 & 0.003 \\
\hline Processing Revenue & 0.04 & 0.09 & 0.85 & 0.63 & 1.13 & 0.77 & 0.57 \\
\hline Commercial Bank Marginal Benefits & 0.04 & 0.09 & 0.85 & 0.63 & 1.13 & 0.78 & 0.57 \\
\hline Sum of Marginal Benefits & 0.74 & 0.16 & 1.46 & 1.04 & 1.74 & 0.93 & 0.73 \\
\hline Sum of Marginal Costs (Table 3-5) & $\underline{1.53}$ & 1.22 & 1.86 & 1.67 & 2.14 & 1.54 & 1.29 \\
\hline Net Social Marginal Cost & 0.79 & 1.06 & 0.40 & 0.63 & 0.40 & 0.61 & 0.56 \\
\hline
\end{tabular}

Table 3-7: Adding selected benefits, discount store check transaction $\$ 43.93$ (\$)

Notes: Numbers may not add due to rounding.

Source: Author's calculations.

\section{$4 \quad$ Case study 3: Specialty electronics store transactions}

Again, the methods employed for the third case study are identical to those used for the first two. We begin with the Coopers survey for specialty electronics store processing costs (replicated in Table 4-1) and then update the numbers to reflect inflation and increases in bank processing fees (see Table 4-2). Following the method outlined for the second case study, we also impute the processing costs electronics specialty stores face for signature debit. Note that PIN debit is not included here because our research indicates that PIN debit is seldom accepted at electronics stores. 


\begin{tabular}{llllll}
\hline \hline & Cash & Check & Visa/MC & Discover & $\begin{array}{l}\text { American } \\
\text { Express }\end{array}$ \\
\hline POS Time & 0.06 & 0.15 & 0.11 & 0.11 & 0.11 \\
Drawer Costs & 0.05 & 0.03 & 0.05 & 0.05 & 0.05 \\
Back Office Costs & 0 & 0 & 0.005 & 0.004 & 0.003 \\
Bank Charges & 0.04 & 1.02 & 2.14 & 1.59 & 3.60 \\
Float Costs & 0.004 & 0.04 & 0.10 & 0.13 & 0.14 \\
Losses & 0.08 & 0.07 & 0.03 & 0.04 & 0.04 \\
Other Direct Costs & 0.06 & 0.02 & 0 & 0 & 0 \\
Per Transaction Total Cost & $\mathbf{0 . 2 8}$ & $\mathbf{1 . 3 4}$ & $\mathbf{2 . 4 5}$ & $\mathbf{1 . 9 3}$ & $\mathbf{3 . 9 4}$ \\
& & & & & \\
Average Receipt for Payment Type & 64.98 & 124.66 & 150.39 & 149.87 & 148.15 \\
Cost Scaled to \$100 of Sales & 0.44 & 1.07 & 1.63 & 1.29 & 2.66 \\
\hline
\end{tabular}

Table 4-1: Per transaction processing costs for various payment instruments electronics specialty store merchants, Coopers (1994 \$)

Notes: Store cards and "Other Cards" excluded. Debit reported as zero transactions. Source: Coopers (1995).

\begin{tabular}{lllllll}
\hline & Cash & Check & $\begin{array}{l}\text { MC/Visa } \\
\text { Credit }\end{array}$ & Discover & $\begin{array}{l}\text { American } \\
\text { Express }\end{array}$ & $\begin{array}{l}\text { Signature } \\
\text { Debit }^{*}\end{array}$ \\
\hline POS Time & 0.06 & 0.15 & 0.12 & 0.11 & 0.11 & 0.12 \\
Drawer/Office & 0.05 & 0.03 & 0.06 & 0.06 & 0.06 & 0.06 \\
Bank Charges & 0.05 & 1.38 & 2.94 & 1.71 & 3.44 & 1.86 \\
Losses & 0.08 & 0.07 & 0.03 & 0.04 & 0.04 & 0.03 \\
Float & 0.01 & 0.02 & 0.02 & 0.02 & 0.02 & 0.01 \\
Other Direct Costs & 0.07 & 0.02 & 0 & 0 & 0 & 0 \\
Per Transaction Total Cost & $\mathbf{0 . 3 2}$ & $\mathbf{1 . 6 7}$ & $\mathbf{3 . 1 6}$ & $\mathbf{1 . 9 5}$ & $\mathbf{3 . 6 7}$ & $\mathbf{2 . 0 8}$ \\
& & & & & & \\
Average Receipt for Payment & 64.98 & 124.66 & 150.39 & 149.87 & 148.15 & 99.30 \\
Type & 0.49 & 1.34 & 2.10 & 1.30 & 2.48 & 2.09 \\
Cost Scaled to \$100 of Sales & 0.49 &
\end{tabular}

Table 4-2: Per transaction processing costs for various payment instruments electronics store merchants, modified (\$)

Notes: ${ }^{*}$ Signature debit is imputed as described for discount stores. Numbers may not add due to rounding. Source: Coopers (1995), updated by authors. 


\begin{tabular}{|c|c|c|c|c|c|c|}
\hline & Cash & Check & $\mathrm{MC} / \mathrm{Visa}$ & Discover & $\begin{array}{l}\text { American } \\
\text { Express }\end{array}$ & $\begin{array}{l}\text { Signature } \\
\text { Debit }\end{array}$ \\
\hline \multicolumn{7}{|l|}{ Merchant Cost, Instrument-Specific } \\
\hline \multicolumn{7}{|l|}{ Avg. Transaction Size (Repeated from } \\
\hline Table 4-2) & 0.32 & 1.67 & 3.16 & 1.95 & 3.67 & 2.08 \\
\hline \multicolumn{7}{|l|}{ Merchant Cost, Cash Transaction Size } \\
\hline$\$ 64.98$ & 0.32 & 1.63 & 1.47 & 0.94 & 1.71 & 1.52 \\
\hline \multicolumn{7}{|l|}{ Merchant Cost, Check Transaction Size } \\
\hline$\$ 124.66$ & 0.39 & 1.67 & 2.65 & 1.65 & 3.12 & 2.47 \\
\hline
\end{tabular}

Table 4-3: Per transaction processing costs for various payment instruments electronics store merchants, fixed transaction Size (\$)

Source: Authors' calculations.

\begin{tabular}{|c|c|c|c|c|c|c|}
\hline & Cash & Check & $\mathrm{MC} / \mathrm{Visa}$ & Discover & $\begin{array}{l}\text { American } \\
\text { Express }\end{array}$ & $\begin{array}{l}\text { Signature } \\
\text { Debit }\end{array}$ \\
\hline a) Merchant Marginal Costs & 0.32 & 1.63 & 1.47 & 0.94 & 1.71 & 1.51 \\
\hline \multicolumn{7}{|l|}{ Consumers } \\
\hline Processing Time & 0.13 & 0.13 & 0.26 & 0.26 & 0.26 & 0.26 \\
\hline Queue Time & 0.13 & 0.13 & 0.26 & 0.26 & 0.26 & 0.26 \\
\hline Explicit Price & 0.03 & 0.04 & 0 & 0 & 0 & 0 \\
\hline Implicit Price* & 0.78 & 0 & 0 & 0 & 0 & 0 \\
\hline Seigniorage & $\underline{0.39}$ & 0 & 0 & 0 & 0 & 0 \\
\hline b) Consumer Marginal Costs & 1.45 & 0.29 & 0.52 & 0.52 & 0.52 & 0.52 \\
\hline \multicolumn{7}{|l|}{ Central Bank } \\
\hline Production & 0.01 & 0 & 0 & 0 & 0 & 0 \\
\hline Processing & $\underline{0.002}$ & 0.03 & 0 & 0 & 0 & 0 \\
\hline c) Central Bank Marginal Costs & 0.01 & 0.03 & 0 & 0 & 0 & 0 \\
\hline \multicolumn{7}{|l|}{ Commercial Banks } \\
\hline ATM Maintenance* & 0.36 & 0 & 0 & 0 & 0 & 0 \\
\hline Production & 0 & 0 & 0.01 & 0.01 & 0.01 & 0.01 \\
\hline Processing & 0.05 & 0.12 & 0.43 & 0.43 & 0.43 & 0.36 \\
\hline Rewards & $\underline{0}$ & 0 & 0.28 & 0.33 & 0.28 & 0 \\
\hline d) Commercial Bank Marginal Costs & 0.41 & 0.12 & 0.72 & 0.77 & 0.72 & 0.37 \\
\hline e) Sum of MC (double counts) & 2.18 & 2.07 & 2.71 & 2.23 & 2.95 & 2.40 \\
\hline f) Social MC (no double counts) & 2.10 & 0.67 & 1.44 & 1.49 & 1.44 & 1.09 \\
\hline
\end{tabular}

Table 4-4: Per transaction processing costs for various payment instruments electronics store parties, cash transaction $\$ 64.98$ (\$)

Notes: Numbers may not sum due to rounding. Sum of MC, e, is equal to $a+b+c+d$. Due to transfers across parties (such as merchant payments to banks), this figure double counts some cost elements. Social Marginal Cost, $\mathrm{f}$, eliminates any transfers that give rise to double counting.

*Assumes \$120 ATM cash withdrawal per visit.

Source: Author's calculations. 


\begin{tabular}{|c|c|c|c|c|c|c|}
\hline & Cash & Check & $\mathrm{MC} / \mathrm{Visa}$ & Discover & $\begin{array}{l}\text { American } \\
\text { Express }\end{array}$ & $\begin{array}{l}\text { Signature } \\
\text { Debit }\end{array}$ \\
\hline a) Merchant Marginal Costs & 0.39 & 1.67 & 2.65 & 1.65 & 3.12 & 2.48 \\
\hline \multicolumn{7}{|l|}{ Consumers } \\
\hline Processing Time & 0.13 & 0.13 & 0.26 & 0.26 & 0.26 & 0.26 \\
\hline Queue Time & 0.13 & 0.13 & 0.26 & 0.26 & 0.26 & 0.26 \\
\hline Explicit Price & 0.03 & 0.04 & 0 & 0 & 0 & 0 \\
\hline Implicit Price* & 0.89 & 0 & 0 & 0 & 0 & 0 \\
\hline Seigniorage & 0.75 & 0 & 0 & 0 & 0 & 0 \\
\hline b) Consumer Marginal Costs & 1.92 & 0.29 & 0.52 & 0.52 & 0.52 & 0.52 \\
\hline \multicolumn{7}{|l|}{ Central Bank } \\
\hline Production & 0.01 & 0 & 0 & 0 & 0 & 0 \\
\hline Processing & 0.002 & 0.03 & 0 & 0 & 0 & 0 \\
\hline c) Central Bank Marginal Costs & 0.02 & 0.03 & 0 & 0 & 0 & 0 \\
\hline \multicolumn{7}{|l|}{ Commercial Banks } \\
\hline ATM Maintenance* & 0.69 & 0 & 0 & 0 & 0 & 0 \\
\hline Production & 0 & 0 & 0.01 & 0.01 & 0.01 & 0.01 \\
\hline Processing & 0.05 & 0.12 & 0.62 & 0.62 & 0.62 & 0.46 \\
\hline Rewards & 0 & 0 & 0.54 & 0.62 & 0.54 & 0 \\
\hline d) Commercial Bank Marginal Costs & 0.74 & 0.12 & 1.17 & 1.25 & 1.17 & 0.48 \\
\hline e) Sum of MC (double counts) & 3.07 & 2.12 & 4.34 & 3.43 & 4.81 & 3.48 \\
\hline f) Social MC (no double counts) & 2.99 & 0.71 & 1.91 & 2.00 & 1.91 & 1.22 \\
\hline
\end{tabular}

Table 4-5: Per transaction processing costs for various payment instruments electronics store parties, check transaction \$124.66 (\$)

Notes: Numbers may not sum due to rounding. Sum of $M C$, e, is equal to $a+b+c+d$. Due to transfers across parties (such as merchant payments to banks), this figure double counts some cost elements. Social Marginal Cost, $\mathrm{f}$, eliminates any transfers that give rise to double counting.

*Assumes \$200 ATM cash withdrawal.

Source: Authors' calculations. 


\begin{tabular}{|c|c|c|c|c|c|c|}
\hline & Cash & Check & MC/Visa & Discover & $\begin{array}{l}\text { American } \\
\text { Express }\end{array}$ & $\begin{array}{l}\text { Signature } \\
\text { Debit }\end{array}$ \\
\hline \multicolumn{7}{|l|}{$\overline{\text { Consumers }}$} \\
\hline Float & 0 & 0.01 & 0.05 & 0.05 & 0.05 & 0 \\
\hline Credit Option & 0 & 0 & 0.18 & 0.18 & 0.18 & 0 \\
\hline Record Keeping & 0 & 0.04 & 0.04 & 0.04 & 0.04 & 0.04 \\
\hline Cash Back Option & 0 & 0 & 0 & 0 & 0 & 0 \\
\hline Signature Debit & 0 & 0 & 0 & 0 & 0 & 0.13 \\
\hline Reward Cards & 0 & 0 & 0.62 & 0.33 & 0.62 & 0 \\
\hline Privacy & 0.65 & 0 & 0 & 0 & 0 & 0 \\
\hline Consumer Marginal Benefits & 0.65 & 0.04 & 0.88 & 0.59 & 0.88 & 0.16 \\
\hline \multicolumn{7}{|l|}{ Central Bank } \\
\hline Processing Revenue & 0.002 & 0.03 & 0 & 0 & 0 & 0 \\
\hline Seigniorage & $\underline{0.39}$ & 0 & 0 & 0 & 0 & 0 \\
\hline Central Bank Marginal Benefits & 0.39 & 0.03 & 0 & 0 & 0 & 0 \\
\hline \multicolumn{7}{|l|}{ Commercial Banks } \\
\hline Float & 0 & 0 & 0 & 0 & 0 & 0.01 \\
\hline Processing Revenue & 0.08 & 1.38 & 1.27 & 0.74 & 1.51 & 1.31 \\
\hline Commercial Bank Marginal Benefits & 0.08 & 1.38 & 1.27 & 0.74 & 1.51 & 1.32 \\
\hline Sum of Marginal Benefits & 1.12 & 1.45 & 2.15 & 1.33 & 2.39 & 1.48 \\
\hline Sum of Marginal Costs (Table 4-4) & 2.18 & 2.07 & 2.71 & 2.23 & 2.95 & 2.40 \\
\hline Net Social Marginal Cost & 1.06 & 0.62 & 0.56 & 0.90 & 0.56 & 0.92 \\
\hline
\end{tabular}

Table 4-6: Adding selected benefits, electronics store cash transaction \$64.98 (\$)

Notes: Numbers may not add due to rounding.

Source: Author's calculations. 


\begin{tabular}{|c|c|c|c|c|c|c|}
\hline & Cash & Check & $\mathrm{MC} / \mathrm{Visa}$ & Discover & $\begin{array}{l}\text { American } \\
\text { Express }\end{array}$ & $\begin{array}{l}\text { Signature } \\
\text { Debit }\end{array}$ \\
\hline \multicolumn{7}{|l|}{ Consumers } \\
\hline Float & 0 & 0.02 & 0.10 & 0.10 & 0.10 & 0 \\
\hline Credit Option & 0 & 0 & 0.34 & 0.34 & 0.34 & 0 \\
\hline Record Keeping & 0 & 0.04 & 0.04 & 0.04 & 0.04 & 0.04 \\
\hline Cash Back Option & 0 & 0 & 0 & 0 & 0 & 0 \\
\hline Signature Debit & 0 & 0 & 0 & 0 & 0 & 0.13 \\
\hline Reward Cards & 0 & 0 & 1.18 & 0.62 & 1.18 & 0 \\
\hline Privacy & $\underline{1.25}$ & 0 & 0 & 0 & 0 & 0 \\
\hline Consumer Marginal Benefits & 1.25 & 0.05 & 1.66 & 1.10 & 1.66 & 0.16 \\
\hline \multicolumn{7}{|l|}{ Central Bank } \\
\hline Processing Revenue & 0.002 & 0.03 & 0 & 0 & 0 & 0 \\
\hline Seigniorage & $\underline{0.75}$ & 0 & 0 & 0 & 0 & 0 \\
\hline Central Bank Marginal Benefits & 0.75 & 0.03 & 0 & 0 & 0 & 0 \\
\hline \multicolumn{7}{|l|}{ Commercial Banks } \\
\hline Float & 0 & 0 & 0 & 0 & 0 & 0.02 \\
\hline Processing Revenue & $\underline{0.08}$ & 1.38 & 2.43 & 1.43 & 2.89 & 2.26 \\
\hline Commercial Bank Marginal Benefits & 0.08 & 1.38 & 2.43 & 1.43 & 2.89 & 2.28 \\
\hline Sum of Marginal Benefits & 2.08 & 1.46 & 4.09 & 2.53 & 4.55 & 2.44 \\
\hline Sum of Marginal Costs (Table 4-5) & $\underline{3.07}$ & 2.12 & 4.34 & 3.43 & 4.81 & 3.48 \\
\hline Net Social Marginal Cost & 0.99 & 0.66 & 0.25 & 0.90 & 0.26 & 1.04 \\
\hline
\end{tabular}

Table 4-7: Adding selected benefits, electronics store check transaction \$124.66 (\$)

Notes: Numbers may not add due to rounding.

Source: Author's calculations.

\section{Sensitivity analysis}

In this section, we consider the impact of variations in key parameters on our net social marginal cost calculations. Considerable heterogeneity exists across transaction types, consumers, and merchants. Even merchants within a single industry can face different payment processing costs due to size, sophistication, and a host of other factors. In addition to this kind of inherent variation, additional variation is introduced through assumptions. While many of the individual cost and benefit components have wide ranges, our conclusions appear to be robust to changes in the specific estimates. Given that we do not have information on the joint distribution of costs and benefits, we focus here on those individual elements that show significant variation or that rely on assumptions.

We illustrate key sensitivities using the grocery store case because we have the most detailed data for this kind of retailer. Nonetheless, the sensitivity discussion below is likely applicable to all three retail environments. We consider three categories of alternatives. First, we examine the sensitivity of our calculations to variations and assumptions 
regarding the opportunity cost of time - an element that affects three cost components. Second, we briefly discuss the considerable variation in the processing fees that commercial banks charge merchants. Finally, we explore the role that consumer heterogeneity plays in determining which payment instruments are used.

\subsection{Opportunity cost of time}

Time spent at the point of sale counter differs considerably across payment instruments. Our analysis could be sensitive to reported point of sale times, as well as to our assumptions about point of sale queues and our use of average wages to estimate the cost of time. To investigate the point of sale time effect, we recalculate the net social marginal cost estimates using FMI high and low point of sale times (means are used in the case studies); the first section of Table 5-1 presents the results. Except where noted below, the methods of calculation for the sensitivity analyses are identical to those used for the case studies. That is, the net social marginal cost varying POS time is calculated by multiplying the POS times - high, mean, and low - by the same clerical wage as used in the case study and then adding all other costs and benefits outlined above. Since point of sale time does not vary by transaction size, we consider the cash transaction size only. Time at the checkout counter clearly affects the overall net social marginal cost estimates, but even if we were to compare costs for the highest times reported for payment cards with the lowest times for paper instruments, our conclusion that payment cards are not more costly for the economy than paper instruments would still hold.

To test the second component of the cost of time, we alter our assumption about the number of people waiting in line behind a payer. In the case studies, we assume that one person waits in line for each grocery transaction. While we were unable to find data on this issue, anecdotal evidence suggests that different kinds of stores are likely to have different typical queues. For example, discount stores are likely to have longer lines on average than electronics specialty stores. Supermarkets are likely to have longer lines than smaller (higher priced) specialty grocery stores or local mom-and-pop grocery stores. Given the uncertainty in line length, we explore the sensitivity of our results to assumptions regarding the queue in the second section of Table 5-1. We find, not surprisingly, that the relatively slower payment instruments, such as checks, are substantially affected by the underlying queue assumptions. With three people in line, the net social marginal costs for credit and debit cards somewhat exceed that for cash, but overall our original conclusion holds. Payment cards do not appear to have higher net marginal social costs than paper instruments. 


\begin{tabular}{|c|c|c|c|c|c|c|c|}
\hline & & Cash & $\begin{array}{l}\text { Non- } \\
\text { Verified } \\
\text { Check }\end{array}$ & Check & $\begin{array}{l}\text { Credit/ } \\
\text { Charge }\end{array}$ & $\begin{array}{l}\text { Signatur } \\
\text { e Debit }\end{array}$ & $\begin{array}{l}\text { PIN } \\
\text { Debit }\end{array}$ \\
\hline \multirow[t]{3}{*}{ POS Time } & High & 0.85 & 1.05 & 0.94 & 0.86 & 0.80 & 0.75 \\
\hline & Mean & 0.80 & 0.99 & 0.87 & 0.81 & 0.76 & 0.70 \\
\hline & Low & 0.77 & 0.95 & 0.81 & 0.75 & 0.71 & 0.66 \\
\hline \multirow[t]{4}{*}{ Queue } & 0 People & 0.66 & 0.66 & 0.56 & 0.57 & 0.53 & 0.49 \\
\hline & 1 Person & 0.80 & 0.99 & 0.87 & 0.80 & 0.76 & 0.70 \\
\hline & 2 People & 0.93 & 1.32 & 1.17 & 1.04 & 0.99 & 0.92 \\
\hline & 3 People & 1.07 & 1.66 & 1.48 & 1.27 & 1.22 & 1.13 \\
\hline \multirow[t]{3}{*}{ Payer Wage } & High & 0.91 & 1.26 & 1.12 & 0.99 & 0.95 & 0.88 \\
\hline & Mean & 0.80 & 0.99 & 0.87 & 0.80 & 0.76 & 0.70 \\
\hline & Low & 0.72 & 0.80 & 0.69 & 0.67 & 0.62 & 0.58 \\
\hline
\end{tabular}

Table 5-1: Sensitivity analysis social net marginal costs varying time cost elements* (\$)

Notes: Calculated for the average grocery cash transaction size of $\$ 11.52$.

*One element is varied at a time. All other cost elements are evaluated at the same level as in the case studies. For example, in the POS Time calculations, only POS time is varied while queue length is set to 1 and payer wage is taken as the mean.

Source: Authors' calculations.

As a final test of the sensitivity of our conclusions to the opportunity cost of time assumptions, we calculate the combined consumer time elements (processing time plus queue time) for different wage percentiles, presented in the bottom section of Table 5-1. Ideally, we would want to examine the cost of using a payment instrument by consumer income percentile, but this information is unavailable. Instead we rely on the 2002 wage distribution as reported by the Bureau of Labor Statistics in the Occupational Employment Survey. In particular, the tenth percentile wage is $\$ 6.95$ an hour, the average (used in the case studies) is $\$ 17.18$ an hour, and the ninetieth percentile wage is $\$ 31.20$ an hour. Even with as illustrating that consumers with higher wages face a higher level of cost for those instruments with relatively longer point of sale times, such as checks. While all net social marginal costs rise with wages, those with longer processing times do so more dramatically. The relative ordering of payment instrument costs stays roughly the same, although verified checks are far more competitive at lower consumer wage rates.

\subsection{Bank charges}

Bank charges are the other obvious cost candidate for sensitivity analysis. The merchant discount assessed on payment card purchases plays a pivotal role in the expense of these cards for retailers. Moreover, fees vary by retailer type and large retailers are often able to negotiate lower fees. Table 5-2 presents FMI's reported high, mean, and low bank charges. The grocery case study calculations are based on the mean charges (updated, as noted earlier). 


\begin{tabular}{lllllll}
\hline \hline & $\begin{array}{l}\text { Cash } \\
(\text { Per \$1000) }\end{array}$ & $\begin{array}{l}\text { Non-Verified } \\
\text { Check }\end{array}$ & $\begin{array}{l}\text { Verified } \\
\text { Check }\end{array}$ & $\begin{array}{l}\text { Credit/ } \\
\text { Charge }\end{array}$ & $\begin{array}{l}\text { Signature } \\
\text { Debit }\end{array}$ & PIN Debit \\
\hline Highest & 0.01 & 0.07 & 0.37 & 2.01 & 0.82 & 0.24 \\
Average & 0.003 & 0.05 & 0.13 & 0.87 & 0.41 & 0.19 \\
Lowest & 0.001 & 0.04 & 0.06 & 0.42 & 0.27 & 0.15 \\
\hline
\end{tabular}

Table 5-2: Bank fee variation, grocery store transactions (1998 \$)

Notes: Fees reported are for instrument-specific average transaction sizes and are therefore not comparable across payment instruments.

Source: FMI (1998).

The bank charges reported in Table 5-2 highlight the diversity in grocery store costs. Even within one narrow retail segment, bank processing fees vary dramatically. One factor behind payment card bank charge variation is FMI's decision to report all card systems together. Processing charges vary substantially across systems, with American Express generally regarded as the most expensive and Discover generally considered the least. A different proportion of sales attributed to each card system will result in different average bank costs for different merchants.

Keep in mind that the charges in Table 5-2 are for 1998. Charge and signature debit card fees have fallen since then, while PIN fees have risen (as reflected in our updated figures for the case studies). Moreover, since bank charges represent transfer payments from merchants to commercial banks (or to independent card systems such as American Express) - not resource costs - the variation in fees does not necessarily translate into variation in net social marginal cost. Ideally we would use similar data to specify a range for commercial bank processing costs, which are actual resource costs and would thus affect our net social marginal cost estimates, but this information is unavailable. Bank charges are a key element in the regulatory investigations involving payment cards - even though we cannot assess their effect on net social marginal costs, the variation in them is worth noting.

\subsection{A note on consumer differences}

Standard cost-benefit analysis, calculated for average agents, does not consider variation among agents. But variation among consumers can be of particular interest since, for retail transactions, consumer preferences dictate to a large degree which instruments are used more heavily. In our calculations, certain benefits are likely to exhibit substantial variation across consumers.

Consumer research suggests that a handful of payment instrument features drive consumer choices (Mantel, 2000). For example, some consumers' primary concern centers on the ability to control the timing of a payment. These consumers want control over when they actually pay a charge, which is different from when they pay the merchant for every payment instrument except for cash. Consumers valuing control are likely to favor paying with checks, credit and charge cards instead of cash or debit. Other consumers focus on the budget enforcement aspects of payment instruments. Here the primary concern is fiscal restraint. These consumers want to ensure they spend within their means. Consumers with a stated preference for debit cards have discussed this benefit. No data exist, to our knowledge, quantifying these consumer benefits. We suspect that such data would help explain the puzzle inherent in Figure 1 in the main paper, which shows that consumers use several different payment mechanisms at each transaction size. 


\section{$6 \quad$ References}

Breitkopf, David (2002) "A Gap in Expectations for Next-Generation ATMs," American Banker, 167: p. 8A.

Breitkopf, David (2000) "Airline Cobrand Cards Reach for New Heights," American Banker, December 12, 165: p.1.

Brito, Dagobert L. and Peter R. Hartley (1995) "Consumer Rationality and Credit Cards," Journal of Political Economy, 103: 402.

Costanzo, Chris (2002) “ATMs Unplugged,” America's Community Banker, 11.

Cox, Rebecca (1989) "Cost-Conscious Banks Seek Ways to Prolong Life of Plastic Cards," American Banker, May 3, p.1.

Food Marketing Institute (1998) A Retailer's Guide to Electronic Payment Systems Costs. Food Marketing Institute: Washington, D.C.

Food Marketing Institute (2003) "2003 Security and Loss Prevention Issues Survey,” p. 78 .

Garcia-Swartz, Daniel D., Robert W. Hahn and Anne Layne-Farrar (2006) "The Move Toward a Cashless Society: A Closer Look at Payment Instrument Economics," Review of Network Economics, 5: page numbers.

Hannan, Timothy H. (2002) "Retail Fees of Depository Institutions, 1997-2001," Federal Reserve Bulletin, September, p. 405-413.

Ingenico (2002) "Online Debit: A Significant Opportunity for Retailers to Reduce their Cost of Business while Improving Customer Service," http://www.ingenicous.com/PDF/debitwp.pdf

Lacker, Jeffrey M. (1993) "Should We Subsidize the Use of Currency?" Federal Reserve Bank of Richmond Economic Quarterly, 79: p. 47-73.

Mulholland, Sarah (2002) "Price Chopper to Use Check Imaging," Supermarket News, December 2, p. 55.

Neumann, Manfred J.M. (1992) "Seigniorage in the United States: How Much Does the U.S. Government Make from Money Production?" Review - Federal Reserve Bank of St. Louis, March/April, 74(2): p. 29-40.

Murphy, Patricia A. (1997) "Supermarkets Try New Methods Against Growing BadCheck Woes," Stores, January.

Pender, Kathleen (2004) "Spending to Build Savings," San Francisco Chronicle, June 13, p. J-1.

Promo Magazine, (2005) "Eight-five Percent of Credit Cards to Carry Rewards by 2009: Research," Promo Magazine, 17 August 2005, http://promomagazine.com/incentives/creditcard_rewards_081705/index.html. 
Sager, Ira \& Michael Arndt (2003) "Flier Miles Keep Airlines Aloft," Business Week, June 16, p. 14.

Stavins, Joanna (1997) "A Comparison of Social Costs and Benefits of Paper Check Presentment and ECP Truncation,” New England Economic Review, July/August: p. 28-44.

Stewart, David W. (1999) “Debit Card Study,” BAI Global: 4316, June 2, 1999, submitted as Expert Report In re Visa Check/MasterMoney Antitrust Litig. (E.D.N.Y. 2000) (No. CV-96-5238).

Wells, Kirstin E. (1996) “Are Checks Overused?” Federal Reserve Bank of Minneapolis Quarterly Review, 2: 2-12. 